\title{
Catalan Morphology and Low-level Patterns in a Network Model*
}

\section{Manuel Pérez Saldanya}

Universitat de València. Departament de Filologia Catalana

Av. Blasco Ibáñez, 32. 46010 València (Spain)

Manuel.Perez-Saldanya@uv.es

\section{Teresa Vallès}

Universitat Internacional de Catalunya. Facultat d'Humanitats

C. Immaculada, 22. 08017 Barcelona (Spain)

tvalles@cir.uic.es

\begin{abstract}
The fact that more specific or low-level morphological patterns may coexist with the most general or abstract ones is a characteristic insight of Cognitive Morphology. According to the bottom-up approach of the model, it is even to be expected that low-level patterns may have a more relevant role than the most inclusive and abstract ones. On the basis of the analysis of an aspect of Catalan inflection (velar verbs of the second conjugation) and one aspect of Catalan wordformation (complex words with the prefixoid radio-), we will show the advantages of incorporating to the model salient low-level patterns and the local paradigmatic relations in which they are based.
\end{abstract}

Key words: Cognitive Morphology, low-level patterns, network model, paradigmatic relations; Catalan.

\section{Table of Contents}

\section{The network model 4. The prefixoid radio-}

2. Paradigmatic relations between real words in the lexicon

3. Catalan velar verbs of the second

5. Conclusions

References

conjugation

\section{The network model}

The nature and function of morphological patterns is a central and distinctive aspect of morphological theory and therefore an issue reflecting the basic assumptions adopted by each model. The divergence of these assumptions is the basis of the

* We are very grateful to a CatJL reviewer and to the CatJL editors for many suggestions which have helped to improve the text. 
well-known differences between the conception of patterns characteristic of generative morphology and that of the cognitive and functionalist morphology of Langacker and Bybee.

The generative proposal on morphological patterns is founded on the purpose of formulating a model that expresses the morphological competence of the speaker in a most economical and least redundant manner. Along these lines, morphological rules represent the most inclusive possible generalization, express the paradigmatic relation between the base and one of its derivatives not found in the lexicon, and have the primary function of generating possible words (which, since they are regular, are not included in the lexicon). From this point of view, general rules allow for the elimination of redundancies from the lexicon. On the other hand, the subpatterns observable in the data are considered unnecessary and grammatically insignificant.

The morphological patterns of cognitive models represent instead regularities of different levels of generalization (the most inclusive patterns may coexist with the most specific ones), emerge from the paradigmatic relations between real words in the lexicon (they are «product-oriented patterns»), and have the function of serving, on the one hand, for the formation and categorization of new words and, on the other, for the analysis and organization of words stored in the lexicon. In this way, morphological patterns do not simplify the lexicon by eliminating redundant information but rather express generalizations regarding the lexicon (Derwing 1990: 252).

From this perspective, subpatterns or low-level patterns can be grammatically significant and can even have a more important role than more general and/or abstract ones. According to Langacker (1988: 288), we do not know for certain that speakers invariably arrive at high-level patterns, which, given their abstract nature, could be of little use in forming and evaluating new expressions. Our purpose is to show the advantages of incorporating salient, low-level patterns and their local paradigmatic relations into the morphological model.

Our approach is based on the network model proposed by Bybee $(1985,1988$, 1995,1999 , 2001). Bybee, like Langacker, maintains that morphology is not a component or module of a grammar containing morphological rules and acting independently from the lexicon. Grammar constitutes one single component formed by both the lexicon and rules or patterns. From this standpoint, the lexicon, morphology, and syntax form a continuum of symbolic units that serve to structure conceptual content for purposes of expression (Cifuentes 1994: 331). The basic characteristics of the network model are the following (Bybee 1996a: 249-250):

a) Words that form part of the lexicon have several degrees of lexical strength, which is largely due to the token frequency of words. Words with a high degree of lexical strength are easier to access, serve as bases for morphological relations, and have an autonomy that makes them more resistant to change and predisposed towards independence from a semantic point of view.

b) Words in the lexicon are interrelated through networks of lexical connections between either identical or similar phonological or semantic features. The par- 
allel phonological or semantic connections define the morphological structure of words.

c) Sets of words that have similar semantic or phonological patterns are mutually reinforced and create emerging generalizations that can be described as schemes or patterns. The productivity of schemes is a direct consequence of type frequency.

Characteristics a) and c) relate language usage to properties of lexical representation. Thus, the level of lexical strength of words and the degree of productivity of their patterns relate to a property of these units (their salience or ease to be accessed) that depends in part on their frequency of use (token frequency and type frequency). Unlike structuralist models, in which the impact of usage is not taken into account in the structure of language, in the network model the frequency of use of the units has an important role in the establishment and maintenance of representations of the linguistic system (Bybee 1995: 428). ${ }^{1}$

\section{Paradigmatic relations between real words in the lexicon}

In the network model, the lexicon contains real words that, given their frequency of use, have been consolidated as units of the linguistic system. One well-known fact favoring this hypothesis is that highly frequent complex words, whether they are regular or not, are activated more easily and with a smaller margin of error. In this model, each lexical unit is the union of a set of semantic features with a group of phonological features (Bybee 1988: 126). The paradigmatic relations between words in the lexicon are based on their identical or similar semantic and phonological features. Figure 1 illustrates these kinds of semantic and phonological relations between the Catalan nouns gat 'cat', gatet 'kitten', gos 'dog', and cadell 'puppy'.

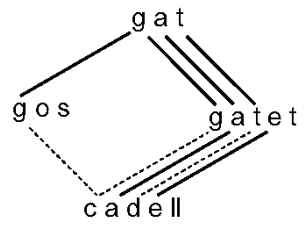

phonological relations

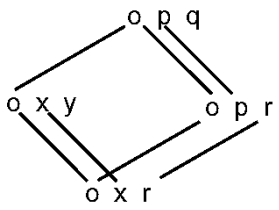

semantic relations

Figure 1. Semantic and phonological relations (based on Bybee 1988: 126).

1. The interaction between language use and language system is an undeniable fact. Language is not confined to a mental prison, and isolated from use. This is why paradigms that do not dissociate language and use are interested in dealing with how and to what extend use affects the linguistic system. 
The nouns gat and gatet are related through phonological connections (the three phonemes they share, as seen on the left of Figure 1) and through semantic connections (because they have common semantic features, conventionally represented by letters, as seen on the right of Figure 1: «0» and «p»). In contrast, the phonological relationship between the nouns gos and cadell is limited to a partial similarity (represented by a dotted line) between the initial phonemes: the voiced and voiceless stops, respectively. Moreover, these words have largely common semantic features, since they only differ in that cadell specifically denotes a young animal. This semantic similarity is expressed through the relationship between «O» and «X»: the common semantic features. On the other hand, gat and gos have the same initial phoneme and a similar structure (CVC), and they are also related from a semantic viewpoint, inasmuch as they designate pets. Likewise, cadell and gatet have a certain similarity at the phonological level: the last syllable is stressed in both, they share the structure $\mathrm{CaCeC}$, and their first two consonants are stops in both cases. Finally, they are semantically related, as both cadell and gatet designate young varieties of pets.

\subsection{Morphemes in the network model}

Parallel phonological and semantic relations allow for the definition of morphological constituents of words, that is, the morphemes that make them up. These morphemes are, in fact, identified by the narrow correlation existing between form and meaning, such as the association between the sequence gat and the features «o» and «p» in the previous example.

The representation of semantic relations as exemplified in Figure 1 presents an inconvenience in that it does not take into account that the smallest units of meaning are morphemes. The semantic relationship between words with common morphemes is a connection between the smallest units of significance, which are not semantic features but rather the morphemes themselves. Moreover, this way of representation could imply that the meaning of words (and of morphemes) is the sum of a series of separable semantic features. ${ }^{2}$ For these reasons, we will explicitly represent the paradigmatic relations between words with common morphemes both the affixal elements as well as the roots - whenever they are transparent and productive morphemes (see Figure 2). ${ }^{3}$ Following this line of reasoning, these connections could be of two different types: the paradigmatic relationship between words with one or more common affixal elements (inflectional or derivational categories) and the paradigmatic relationship between words with the same root (word families) (Vallès 2003, 2004).

2. Features identifiable by way of a componential analysis can have different degrees of salience or prototypicality (Geeraerts 1992: 222-223; 1995: 33). Moreover, the meaning can be metaphorical or metonymical and of an encyclopedic nature.

3. As shown in Figure 1, Bybee's connections are not morpheme to morpheme but phoneme to phoneme in such a way that the border between morphemes is not expressed explicitly but implicitly — deduced from the comparison of the base and the derivative- in the representation of the derivative series. Regarding the disadvantages that Bybee alleges against explicit morphological segmentation and the ways to avoid them, see Vallès (2003: 145-148). 


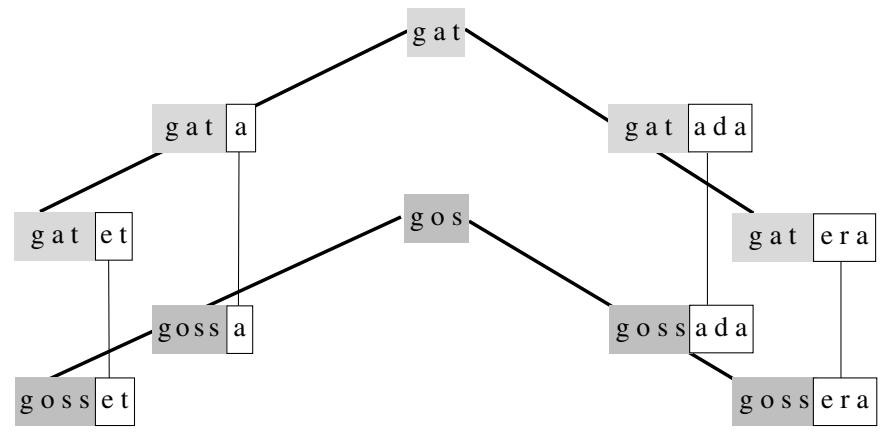

Figure 2. Morphological relationships. ${ }^{4}$

Psycholinguistic studies contribute an important argument regarding the morphological relationships among words. For instance, research in word recognition has provided evidence for the existence of a morphological parser, that is "an automatic and obligatory component of the word recognition process for both existing words and novel multimorphemic forms" (Libben and Almeida 2002: 223). This parser "is responsible for the isolation and identification of morphological constituents of multimorphemic words" and "makes it possible for language users to understand novel or infrequent multimorphemic words by breaking such words into their morphological constituents so that an interpretation of the novel form can be constructed on the basis of those constituents" (Libben and Almeida 2002: 213).

In order to perform this morphological analysis of words in the lexicon and of neologisms, speakers must compare words and search for similarities between their morphemes. In other words, they must establish paradigmatic relations between words with common morphemes, such as we propose to express explicitly through the network model. For example, in order to interpret a Catalan neologism like bicultural, one must compare this complex word with other Catalan words formed with bi- (bimotor, bidireccional, and bidimensional) and with members of its own family of words (cultura, cultural, multicultural, intercultural, transcultural...). Without this comparison, the neologism would be unparsable.

\subsection{Other paradigmatic relations}

The model not only allows for the recognition of morphemes that constitute complex words, but it also allows for the definition of other relations that extend beyond morpheme boundaries or do not identify with any concrete morpheme. Regarding the first

4. Gat 'cat' and gos 'dog' are accompanied by gata and gossa (refering to their respective female counterparts), gatet and gosset (refering to their young), gatada 'colony' and gossada 'pack', and gatera 'flap door for cats' and gossera 'doghouse'. 
possibility, let us imagine hypothetical data like the following (upper-case letters represent roots and lower-case letters represent affixes) (Vallès 2004: 97-102):
(1) a. B, C, D, E, F...
b. $\mathrm{aB}, \mathrm{aC}, \mathrm{aD}, \mathrm{aE} .$.
c. $\mathrm{aBg}, \mathrm{aCg} \ldots$
d. aCgh, aDgh, aEgh...

Starting with these data, from a top-down perspective, linguists could formulate a general rule for the prefix $a$-, and general rules for the suffixes $-g$ and $-h$. In contrast, with a bottom-up approach such as the one adopted by the network model, the same data could suggest not just the general patterns of the affixes $a-,-g,-h$, but also the subpatterns - $g h$ (such as the Catalan forms -ització '-ization', -alment '-ally': periodització, setmanalment 'weekly'...), a_g (des_ció 'un_tion': desinformació, desmotivació...) and a_gh (anti_ització 'anti_ization': antiglobalització, antimilitarització...). What changes from one to another is not just the inclusion of subpatterns as a relevant factor. The true difference is that, from a top-down perspective, the general rules are a priori considered significant, whereas the subpatterns are not. In contrast, from the perspective adopted by a usage-based model, the existence of patterns and subpatterns in grammar becomes an empirical question.

We have shown that the model can define morphological relations, not just at a level greater than morphemes but also at a lesser level. This second possibility can be exemplified in the participles of Catalan verbs of the third conjugation. The regular participles of this conjugation follow a very general pattern that can be formulated as in $(2):^{5}$

(2) [root [íd]]: dormit 'slept', partit 'sliced', dividit 'divided' ...

Within Catalan irregular verbs, there is a group of third conjugation verbs that takes on a distinctive participle ending in -ert. The group is rather small since this characteristic of the participle is determined in part by the final consonants of the root. As shown in (3) with the infinitive forms, in all cases the final consonant of the lexical root is a liquid and the preceding consonant is labial:
a. -br-: obrir, cobrir
'to open', 'to cover'
b. -bl-: establir, reblir
'to establish', 'to fill with rubble'
c. -pl-: omplir, complir
'to fill', 'to attain'
d. $-f(e) r$-: oferir, sofrir
'to offer', 'to suffer'

In the participle the liquid disappears if it is an $r$ (and also disappears the preceding $e$ of oferir), but remains if it is an $l$ : 
(4)
a. -bert: obert, cobert
b. -blert: establert, reblert
c. -plert: omplert, complert
d. -fert: ofert, sofert

The pattern that accounts for this irregular participle can be formulated as in diagram (5), where $\mathrm{X}$ refers to unspecified phonological content, the braces to preferred but non-obligatory features or segments, and the parentheses to optional features or segments. ${ }^{6}$

(5) $\left[\left[_{\text {root }} X\left[\begin{array}{l}\text { consonant } \\ \{\text { bi }\} \text { labial }\end{array}\right]\right.\right.$ (1)] Ért $]$

As the diagram shows, the (bi)labial consonant and the liquid intervene in the morphological relation involving the irregular participles ending in -ert, in which the boundary between the lexical root and the inflectional ending become fuzzy. We observe that, while this morphological relation is local, it is at the same time also very strong because the participles share a high number of common features, which is precisely what gives cohesion and stability to the group. As Bybee (1996b) has pointed out, language shows a clear parallelism to memory in this sense. We normally remember habitual, recurring, and repeated events, but we also remember unconnected details, redundancies, and generalizations of a very local nature. In the same way, speakers are capable of formulating very general and abstract diagrams like the one in (2) but also very local ones like the one in (5). Low-level patterns can therefore be of grammatical significance and even have a role as important as the most general or abstract patterns.

Having presented the general characteristics of the model, in the following sections we will analyze an aspect of inflection and one of derivation. Specifically, we focus on the Catalan velar verbs of the second conjugation and on complex words using the combining form radio-.

\section{Catalan velar verbs of the second conjugation}

The second conjugation is the most irregular and least productive Catalan verbal inflection, but some of the most frequent verbs follow this pattern. Among the verbs traditionally considered irregular, the so-called «velar» verbs are of special importance. Certain forms of the paradigm display a velar consonant between the

6. In the pattern in (2), the final alveloar consonant is voiced but becomes voiceless word finally, as seen by contrasting the masculine form (dormit) and the feminine form (dormida) of the participle, 'slept'. However, in (5), the consonant remains voiceless, demonstrated by the fact that there is no variation between the masculine form (obert) and the feminine form (oberta) of the participle, 'opened'. A similar phonetic variation will be explored in greater detail in section 3. 
Table 1. Paradigm of the verb moldre 'to grind'.

\begin{tabular}{|c|c|c|c|c|c|}
\hline \multicolumn{6}{|c|}{ INDICATIVE } \\
\hline & Present & IMPERFECT & SIMPLE PAST & FUTURE & CONDITIONAL \\
\hline 1 st sg & molc & molia & molguí & moldré & moldria \\
\hline 2nd sg & mols & molies & molgueres & moldràs & moldries \\
\hline 3rd sg & mol & molia & molgué & moldrà & moldria \\
\hline $1 \mathrm{st} \mathrm{pl}$ & molem & molíem & molguérem & moldrem & moldríem \\
\hline 2nd pl & moleu & molíeu & molguéreu & moldreu & moldríeu \\
\hline $3 \mathrm{rd} \mathrm{pl}$ & molen & molien & molgueren & moldran & moldrien \\
\hline \multicolumn{3}{|c|}{ SUBJUNCTIVE } & \multirow[t]{2}{*}{ IMPERATIVE } & \multicolumn{2}{|c|}{ NONPERSONAL FORMS } \\
\hline \multirow{7}{*}{$\begin{array}{l}1 \mathrm{st} \mathrm{sg} \\
2 \mathrm{nd} \mathrm{sg} \\
3 \mathrm{rd} \mathrm{sg} \\
1 \mathrm{st} \mathrm{pl} \\
2 \mathrm{nd} \mathrm{pl} \\
3 \mathrm{rd} \mathrm{pl}\end{array}$} & Present & IMPERFECT & & INFINITIVE & Participle \\
\hline & \multirow{6}{*}{$\begin{array}{l}\text { molgui } \\
\text { molguis } \\
\text { molgui } \\
\text { molguem } \\
\text { molgueu } \\
\text { molguin }\end{array}$} & \multirow{6}{*}{$\begin{array}{l}\text { molgués } \\
\text { molguessis } \\
\text { molgués } \\
\text { molguéssim } \\
\text { molguéssiu } \\
\text { molguessin }\end{array}$} & \multirow{6}{*}{$\begin{array}{l}\text { mol } \\
\text { molgui } \\
\text { molguem } \\
\text { moleu } \\
\text { molguin }\end{array}$} & moldre & \multirow{6}{*}{$\begin{array}{l}\text { mòlt } \\
\text { mòlta } \\
\text { mòlts } \\
\text { mòltes }\end{array}$} \\
\hline & & & & & \\
\hline & & & & GERUND & \\
\hline & & & & molent & \\
\hline & & & & & \\
\hline & & & & & \\
\hline
\end{tabular}

root and the inflectional ending. Table 1 shows the paradigm of the verb moldre 'to grind', with the velar forms marked in italics.

As can be observed, inflected forms with the velar consonant include the first person singular present indicative; the third person singular, first plural, and third plural in the imperative tense, and all persons in simple past, present subjunctive, and imperfect subjunctive. In addition, verbs like beure 'to drink' also acquire a velar in the participle (begut 'drunk') and others show certain peculiarities in their distribution of velar forms. Moreover, the velar is voiceless in the first singular person of the present indicative but voiced in all other cases. Keeping in mind that this distinction is prompted by the phonic context — namely, all word-final obstruents are voiceless - it can be argued that there is no morphological difference between these voiced and voiceless velars and that both cases deal with the phoneme /g/ (Bonet and Lloret 1998: 103-105).

\subsection{The status of the velar consonant}

The status of the velar consonant becomes problematic for models based on the segmentation of morphological constituents. Due to this difficulty, the velar segment has been characterized in different ways in Catalan linguistic studies. For some researchers, the velar consonant is identified with the final segment of one of the allomorphs of the verbal root (Badia 1994: 574-578; Mascaró 1983: 155194; Roca Pons 1968: 231). Other researchers, however, have argued that the velar 
segment is a constituent independent of both the root and the inflectional affixes (Malkiel 1974; Perea 2002: 597-601; Pérez Saldanya 1998: 73-75; Viaplana 1984, 2005; Wheeler 1993: 196). Finally, it has also been argued that the velar segment is an empty morph (DeCesaris 1988) or a lexically-conditioned epenthetic consonant (Hualde 1992: 410).

The diversity of these linguistic proposals is due, in large measure, to the fact that arguments supporting one theory or another readily exist. From an etymological perspective, the answer cannot be unitary since in some cases the velar consonant goes back to the final consonant of the root of the Latin equivalent of the present, as in (6a), whereas in other cases it derives from a consonant replacing the inflectional marker $U(/ \mathrm{w} /)$, which appeared in some strong perfects (i.e., simple past tense) (6b).

a. $\mathrm{DIC}>$ dic; DICAM $>$ diga (later digui)...

b. VALUI > valc (later valguí)...; VALUISSEM > valgués...

From a synchronic standpoint, the answer is not unitary either. For a verb like beure 'to drink', it might seem that the velar is part of the root (or the velar allomorph of the root), since the constituent beg-follows the canonical structure (CVC) of verb roots in Catalan and the velar consonant and others that clearly are part of the root are in a complementary position, like $v$ or the glide $u$ [w] (in bevia or beus, for example). ${ }^{7}$ As for verbs like moldre 'to grind', on the other hand, it seems that it is an independent element added onto the canonically structured root mol-. Finally, from a functional point of view, if it is true that the velar has no particular meaning, then it is also true that its presence or absence allows us to distinguish between the first and third singular persons in the present indicative (molc and $\mathrm{mol}$, respectively) and the present indicative and present subjunctive in the first and second plural persons (molem and moleu vs. molguem and molgueu, respectively). In sum, the velar segment finds itself at the intersection between the root and the endings since it exhibits properties of one or the other without belonging itself to either one or the other.

As has been indicated, a network model is not based on the segmentation of morphological constituents but on the relationships of form and meaning (or function). In addition, these relationships of forms and meaning may exactly coincide with morpheme boundaries but could also surpass or fail to reach these boundaries. In the case analyzed here, the model demonstrates this equidistance in the sense that it connects the velar of different verbs with inflectional forms (i.e., the endings) and also with different forms of the same verb (i.e., the root):

7. In the Catalan varieties in which $v$ maintains its labiodental pronunciation, the glide $u / \mathrm{w} / \mathrm{can}$ be derived from $v$ since it appears only in coda position. In the Catalan varieties in which $b$ and $v$ merged in favor of $b$, two different phonemes must be considered (i.e., $/ \mathrm{b} /$ and $/ \mathrm{w} /$ ). 


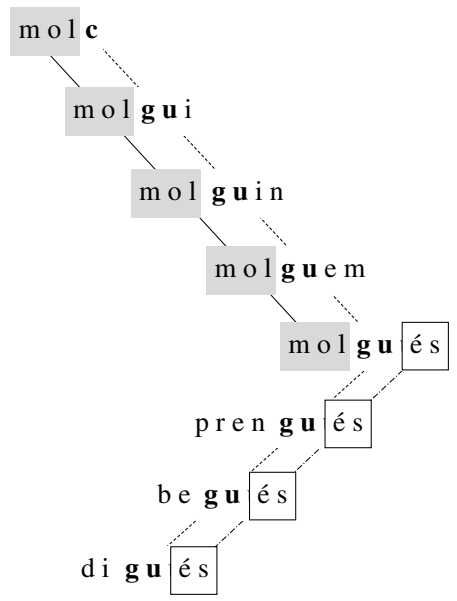

Figure 3. Paradigmatic relations between velar forms.

Based on the evidence of the position and function of the velar segment, we can conclude that the velar acts as a marker for verbal class and, specifically, as a thematic extension, parallel to the thematic vowel (Perea 2002: 597-601; Pérez Saldanya 1998: 73-75; Viaplana 1984, 2005; Wheeler 1993: 196).

\subsection{Patterns in velar verbs}

Morphological patterns arise from paradigmatic connections, as the previous section has illustrated. In the case of velar verbs, the pattern could be described as the velar followed by the endings, which appear in all forms except in the first singular person of the present indicative, which does not have any affix. Another aspect of the pattern is that it could also indicate that the velar is preceded by a very specific group of segments, as can be seen in (7).

(7) a. stressed vowel + n: prenc, estenc, tinc, vinc, ponc, fonc...

'I take', 'I extend', 'I have', 'I come', 'I lay', 'I melt' .. .

b. stressed vowel +1 : molc, dolc, solc, tolc...

'I grind', 'I grieve', 'I use to', 'I remove'...

c. stressed vowel $+\mathrm{j}$ : caic

'I fall down'

d. stressed vowel: $\quad$ bec, moc, dic, duc, plac, conec...

'I drink', 'I move', 'I say', 'I carry', 'I please', 'I know' ...

Finally, the pattern could also indicate that the vowel — stressed if the root is tonic - is usually preceded by a consonant at the beginning of the word, even though there are also cases of two consonants together (like prenc 'I take'), cases 
of a single vowel alone (like hagués 'I had (subjunctive)'), or cases in which the stressed vowel is preceded by an unstressed vowel (escric 'I write', conec 'I know'). The formula in (8) illustrates the aforementioned pattern.

$$
\left[\{\# \# C\}+V_{\text {stressed vowel }}+(n / 1 / j)+g+\{\text { endings }\} \# \# \#\right.
$$

The lexical connections also highlight how irregular verbs follow certain patterns that minimize irregularities and favor learning. Not all forms of a paradigm are equally representative. The most frequent forms are usually the most morphologically simple, and both the frequency and simplicity of their forms reinforce their accessibility to the speaker and the degree to which they are representative of the paradigm. In fact, this difference in how well different forms represent an entire paradigm establishes the distinction between basic and derivative forms.

As the data indicate, the most basic forms of the paradigm are the third and first singular persons of the present indicative. For a verb like conèixer 'to know', the two forms allow for the derivation of the rest of the paradigm by adding the appropriate endings: ${ }^{8}$
a. conec $\rightarrow$ PS: conegui, coneguis...
SPast: coneguí, conegueres...
IS: conegués, coneguessis...
3rd sing, 1st pl, 3rd Imp: conegui, coneguem, coneguin
Part: conegut
b. coneix $\rightarrow$ 2nd sing, 1st, 2nd, 3rd pl PI: coneixes, coneixem...
II: coneixia, coneixies...
2nd sing, 2nd pl Imp: coneix, coneixeu
Inf: conèixer
F: coneixeré, coneixeràs...
$\mathrm{C}$ : coneixeria, coneixeries...
G: coneixent

In this case, the organization of the paradigm is as iconic and compositional as possible in the sense that all forms can be derived by adding the appropriate endings to the two basic forms. In other cases, in addition to the two basic forms, there is a third one, which corresponds to the forms adopted by the first and second plural persons of the present indicative. The verb coure 'to cook', for example, follows this model:

8. The following abbreviations are used: present indicative (PI), simple past (SPast), imperfect indicative (II), future (F), conditional (C), present subjunctive (PS), imperfect subjunctive (IS), imperative (Imp), infinitive (Inf), gerund (G), and participle (Part). 
(10) a. coc

b. cou

c. coem, coeu $\rightarrow$ PS: cogui

SPast: coguí, cogueres...

IS: cogués, coguessis...

3rd sing, 1st pl, 3rd pl Imp: cogui, coguem, coguin Part: cogut

$\rightarrow \quad$ 2nd sing, 3rd pl PI: cous, couen

2nd sing Imp: cou

Inf: coure

F: couré, couràs...

C: couria, couries...

$\rightarrow \quad$ II: coïa, coïes...

2nd pl Imp: coeu

G: coent

In this case, the level of iconicity of the paradigm is not as high, given that, in the case of the third basic form, the derivative forms are not recovered by adding on endings but by changing them.

There are even more specific cases, but the two examples offered serve to demonstrate how paradigms and relationships are established. In dealing with more recurring patterns, it is also possible to define them by way of more general and abstract patterns. ${ }^{9}$ Verbs like conèixer 'to know', for example, would follow the formula in (11a), where it would be necessary to specify the forms adopted by each one of the patterns. Verbs like coure 'to cook', instead, would follow the formula in (11b). Finally, verbs like moldre 'to grind' or vendre 'to sell' follow the formula in (11c); like conèixer, they have two basic forms but are different in that the velar does not alternate with any other consonant. ${ }^{10}$
a. $[\mathrm{Xg}\{$ endings $\}]-[\mathrm{XC}$ \{endings $\}]$
b. $[\mathrm{Xg}$ \{endings $\}]-[\mathrm{XC}$ endings $\}]-[\mathrm{X}$ endings $]$
c. $[\mathrm{Xg}$ \{endings $\}]-[\mathrm{X}$ \{endings $\}]$

\subsection{The velar verb and analogical processes}

Velar verbs have undergone a set of changes through analogy, which can be described in a simple way using the network model. In the next section, we provide evidence for two changes through analogy in velar verbs: the first dealing with interparadigmatic changes, which turn an originally non-velar verb into a velar one, and the second dealing with intraparadigmatic changes, which turn originally non-velar, inflectional forms into velar ones.

9. See Mascaró (1983: 181-185) for a more detailed analysis of these kinds of patterns.

10. In this model, the consonant $d$ appearing in the infinitive (moldre), the future (moldré), and the conditional (moldria) is omitted because it is considered to be epenthetic, that is, it is motivated by the phonetic context so as to prevent contact between the $l$ or $n$ of the root and the following tap consonant in the aforementioned forms (Bonet and Lloret 1998: 91-93). 


\subsubsection{The velarization of the verb donar}

Analogy often occurs through a process of paradigmatic leveling, which adds uniformity and transparency to inflectional paradigms. In some cases, nevertheless, the change seems to go in the opposite direction, as regular forms are replaced with irregular forms. A rather indicative example of these irregular changes can be found in the verb donar 'to give'. This verb has a relatively high frequency of use and, moreover, belongs to the most regular and productive conjugation class in Catalan (i.e., the first conjugation). These characteristics give it qualities of stability and resistance to change. Nevertheless, the verb donar has colloquial forms in some Catalan varieties and has adopted a mixed form of conjugation, regular in (12a) and velar in (12b).

(12) a. donés, dóna...; donava, donaves...; donaré...; etc.

b. donc; dongui, donguis...; dongués, donguessis...

The velarization of this verb through analogy can be explained in simple terms using the network model, as this model takes into account lexical connections based on phonological and semantic similarities, localized yet quite strong. In fact, the verb donar 'to give' establishes a very powerful yet narrow relationship with another velar verb: the verb prendre 'to take from'. The relationship is narrow because it depends on meaning as well as form. In terms of meaning, donar and prendre refer to reciprocal actions in which the same two participants intervene: one who gives and one who receives. In terms of form, in both cases the root ends in a highmid stressed vowel followed by $n$. The following formula in (13) illustrates the interrelationship between these two verbs:
a. Meaning: if $\mathrm{A}$ gives $\mathrm{X}$ to $\mathrm{B}$, then $\mathrm{B}$ takes $\mathrm{X}$ from $\mathrm{A}$
b. Form: ${ }_{\text {root }} \mathrm{C}(\mathrm{C})$ [high-mid vowel] n]: pren-, don-

The connection is local, but at the same time it is very intense; and this intensity motivates the adoption by donar of the pattern of velar verbs, abandoning the regular pattern of the verbs of the first conjugation.

\subsubsection{Relationships within paradigms: the velar and the thematic vowel}

Analogical changes also result within the same paradigms with velar forms. As can be seen in previous Table 1, in many velar forms the velar consonant is followed by a stressed $e$ : molguem, molgueu, molgué... The presence of both constituents in many forms makes up a subpattern that is reinforced because the two constituents behave functionally as markers of verbal categories. Thus, the $e$ is associated with the thematic vowel and is therefore a marker of the second conjugation, whereas the velar consonant identifies with the velar extension and is therefore a marker of the subcategory within the verbs of the second conjugation.

This narrow relationship, in fact, explains the tendency of the velar consonant to become widespread in colloquial registers in all contexts in which the thematic 
vowel is used. The further innovation of velars, all in all, has neither the same intensity nor the same geographical extension in all Catalan varieties. It is quite generalized in the gerund (molguent instead of the standard molent), but it has a more limited and dialectal character in other cases. The velarization of infinitives with a stressed $e$ is very frequent in the Catalonia dialect (sapiguer, capiguer, and, to a lesser degree, volguer, instead of the standard saber 'to know', cabre 'to fit', and voler 'to want'), whereas the velarization of the first and second plural person forms in the present indicative is quite habitual in central Valencian speech (coguem and cogueu in place of the standard coem and соеu).

\section{The prefixoid radio-}

The importance of paradigmatic relations is not exclusive to inflection. They are also highly relevant in the formation of new words, as previous research has pointed out. ${ }^{11}$ An important advantage of the network model is precisely its ability to express all kinds of paradigmatic relations existing among the various units that make up grammar. We illustrate these kinds of relationships through the study of the word formation processes with the combining form radio-.

\subsection{The morphological pattern radio-}

A conventional description of the word formation pattern with the combining form radio- would specify only its phonological form /rádio/, the semantic content of 'radio', and the grammatical category of the base and the derivative (it creates nouns from nouns). This description, however, would not take into account that the pattern is not an isolated element of the Catalan morphological system and that it exhibits a series of paradigmatically determined features.

The so-called «prefixoids» (radio-, euro-, eco-, narco-, tele-, petro-, etc.) are initial-combining forms of recent creation that have been introduced through the imitation of neoclassical combining forms, often disseminated through the mass media (Vallès 2004: 174-186). They result from the truncation of a word (radioreceptor 'radio receiver', europeu 'European', ecologic 'ecological'...) and follow the tendency of colloquial registers to shorten complex words to the first two syllables (although, for this reason, the prefixoid sometimes is identical to the truncated word: radio- and ràdio).

In general, the morphological patterns of prefixoids share the following characteristics:

11. Among those who emphasize the role of paradigmatic relations in word formation are Bauer (1997, 2001); Becker (1993); Booij (1997, 2005); Camus (1996, 1997, 1998a, 1998b); Camus and Miranda (1996); Geeraerts (1995, 2002); Haspelmath (2002); Pounder (2000); Rifón (2001, 2002); Rubba (1993, 1998); Vallès (2003, 2004), and van Marle (1985, 1994). See also Bybee (2001: 117). 
(14) a. The phonological content of the pattern:

- Generally it has two syllables, whose first one is stressed. If it has three, it follows the syllabic structure $\mathrm{CVC}(\mathrm{C}) \mathrm{VV}$ (radio-, biblio-).

- Usually it ends in the vowel -o.

- It is identical to a fragment of the original complex word.

b. The semantic content:

- It creates a modifier-head relationship with respect to the base. ${ }^{12}$

- It keeps the semantic content of the original noun or adjective.

Prefixoids are different from the rest of combining forms for various reasons. Unlike other combining forms of Greek or Latin origin, such as cron(o) (cronòmetre 'chronometer', sincronia 'synchrony'), prefixoids only appear in the initial position of a word. Whereas prefixoids ending in -o require this vowel, other initial-combining forms display a vowel or not, depending on the context (fonema 'phoneme', fonometre 'phonometer'). The final vowel of a prefixoid is part of the original complex word, whereas in other combining forms, the vowel - $o$ only appears in this initial element (electro- vs. elèctric, socio- vs. social). Since in prefixoids no phoneme is added to the shortened form, and since they do not have allomorphs, they are completely transparent. Thus, from a phonological perspective, they are invariable and identical to the truncated form of the corresponding complex word, and, from a semantic viewpoint, they carry the semantic value of the original complex word.

Prefixoids constitute a subcategory of combining forms that is homogenous and relatively open. In the network model, the great similarity among various prefixoids can be expressed as a paradigmatic relation of a local nature among the morphological patterns of radio-, eco-, euro-..., which may have created a more abstract pattern with the common features mentioned in (14). In this way, the model provides an understanding of the narrow similarity among the morphological patterns of these prefixoids, as well as the formation of new members within the category (such as the Catalan prefixoids publi- 'advertising' in publireportatge 'advertorial, infomercial', publitramesa 'mailing', publiinformació 'publicity', and petro'petroliferous' in petrodòlar and petroeconomia).

\subsection{The semantic content of radio-}

We have argued that the morphological conclusions provided by subpatterns in theoretical models vary depending on whether a top-down or bottom-up approach is adopted. As an example, we analyze the different meanings of radio- in a corpus of Catalan articles from the press. ${ }^{13}$

12. Along these lines, it is necessary to distinguish between the prefixoid radio- (radionovel-la 'radio serial', where radio- has the function of modifier) from the truncated word radio (as in the copulative compound radiodespertador 'alarm clock-radio'). In the latter, the first constituent is not a prefixoid but instead a noun; radiodespertador is a compound formed by two nouns, that is, two autonomous roots.

13. See Pérez Lagos (1985) for an analysis of the entries in the Diccionario de la Real Academia Española in which the Spanish equivalent of this formation appears. 
Table 2. The meanings of radio-.

\begin{tabular}{|c|c|c|}
\hline \multirow[t]{2}{*}{ Semantic Value } & \multicolumn{2}{|l|}{ EXaMPLES in CaTALAN } \\
\hline & CONVENTIONAL WORDS & NEOLOGISMS \\
\hline $\begin{array}{l}\text { a. 'radio', 'radio } \\
\text { communications' }\end{array}$ & $\begin{array}{l}\text { radionovel-la 'radio serial', } \\
\text { radiooient 'radio listener', } \\
\text { radioaficionat 'radio-amateur', } \\
\text { radiotaxi, radioenllaç 'radio link', } \\
\text { radiodifusió 'broadcasting', } \\
\text { radiotelèfon, radiotelègraf } \\
\text { radio-amateur', } \\
\text { radiopredicador 'radio } \\
\text { preacher', radiopatrulla 'radio } \\
\text { patrol car', radioemissor } \\
\text { 'radio transmitter', } \\
\text { radiocontrol... }\end{array}$ & $\begin{array}{l}\text { radiofórmula, radiodrama, } \\
\text { radioteatre, radiotertúlia } \\
\text { 'radio discussion group', } \\
\text { radioafecció 'radio affinity', } \\
\text { radioescolta 'listener', } \\
\text { radiopirata 'pirate or illegal }\end{array}$ \\
\hline b. 'radioactivity' & $\begin{array}{l}\text { radiodiàgnostic, radioteràpia, } \\
\text { radioisòtop }\end{array}$ & radiocirurgia 'radio surgery' \\
\hline c. ' $\mathrm{X}$ rays' & radiografia, radiologia & \\
\hline $\begin{array}{l}\text { d. 'radius bone } \\
\text { of the forearm' }\end{array}$ & radiohumeral & \\
\hline
\end{tabular}

The meanings of radio- as compiled in Table 2 express the lowest common denominator in semantic terms for each group of complex words. This search for patterns in data often performed by linguists is also conducted by speakers, albeit in a more spontaneous manner. However, the patterns detected by one or the other are not necessarily the same (Bybee 1985: 131). The reason for this discrepancy is that linguists have traditionally adopted a top-down approach in order to form rules as general as possible (something that speakers do not always do). From a top-down perspective, subpatterns - at best- hold merely a marginal interest because they are considered unnecessary.

From a top-down approach, the first three meanings of radio- (Table 2.a-c) are irrelevant, as they could be included in a single hyperonym. The semantic value of 'radiation' could be attributed to radio- since all three cases deal with the emission and propagation of waves, either of high frequency (radioactivity, $\mathrm{X}$ rays) or low frequency (radio transmission). In a top-down approach, only two different meanings of radio- would need to be differentiated: ${ }^{14}$

14. In addition to the semantic value of radio-, these two groups of complex words exhibit another important difference. The internal structure of words corresponding to meanings (a)-(c) in Table 2 is that of modifier-head; in contrast, words carrying the meaning (d) have a relationship of coordination. In the latter, radio- has an adjective function 'related to radius' that maintains a relationship of coordination with the other constituent, also an adjective (humeral, carpal, etc.), in such a way that radiohumeral means 'related to radius and to the humerus'. 


\section{a. radio- 'radiation' (meanings a-c in Table 2) \\ b. radio- 'radius bone of the forearm' (meaning $\mathrm{d}$ in Table 2)}

From this perspective, these two rules or patterns would be sufficient to account for all complex words formed with radio-. However, this simplicity or economy also has its disadvantages. The description of data is very imprecise as it fails to account for the various semantic «subpatterns» corresponding to meanings (a)-(c) in Table 2. The information provided by these subpatterns would have to be individually attributed to each lexical entry as idiosyncratic information, and this rule would fail to reflect a subpattern easily observed by speakers, such as the one shared by the sample words in Table 2.a: radionovel-la, radiooient, radiopirata, etc. Thus, there would be no way of explaining why only one of the three meanings of radioin (15a) is productive: 'radio, radio communications' (Table 2.a). A final disadvantage of a top-down approach is the lack of plausibility of a rule with the meaning of 'radiation', as the cohyponymic relation between the meaning of radio- in radiografia ' $\mathrm{X}$ rays' and in radionovel-la 'radio' is fuzzy for many speakers.

Cognitive grammar adopts a bottom-up orientation because it is a usage-based approach. Thus, patterns of all levels are admitted, from the most general to the most specific. In this case, the patterns in the complex words with meanings (b)-(d) in Table 2 are probably not widespread enough in language for speakers to be able to analyze these words and recognize their meanings in the new formations. Moreover, only specialists would be able to relate the meaning of 'radio' with that of 'radioactivity' and ' $\mathrm{X}$ rays' by way of the hyperonym, or their common meaning, 'radiation'. Thus, it must be the case that the hyperonymic connection is absent from the mental grammar of speakers. The productive morphological pattern radioshows only one meaning: the semantic value of 'radio', 'radio communications' (Table 2.a).

\subsection{Paradigmatic relations and neology}

Traditionally, the formation of a neologism in Catalan like radiopirata 'illegal radio-amateur' has been explained through morphological rules, such as the rule governing the prefixoid radio-. From this point of view, only one rule is needed to account for the neologism. The monorelational rule $\left[[\text { radio- }][\ldots]_{N}\right]_{N}$ expresses the relationship between the prefixoid radio- and the base pirata, but does not take into account all the paradigmatic relations that, together with contextual information, allow the speaker to encode and decode radiopirata.

Let us imagine that a reader of the following Catalan newspaper article encounters this neologism for the first time (the segments in italics contribute to the understanding of the new word): 15

15. For expository purposes, we adopt the point of view of the reader who attempts to decode the neologism. For the inverse process of encoding, the speaker has the same linguistic resources at his or her disposal. 
Un radiopirata crea el pànic en el trànsit aeri de Brussel-les. Un home ha aconseguit desencadenar el pànic entre els aviadors i els controladors aeris amb missatges que fa arribar als pilots que es dirigeixen a l'aeroport de Brussel-les. La policia està buscant intensament aquest fals controlador aeri, que domina perfectament el llenguatge internacional de l'aviació —en anglès—, aconsegueix arribar a les freqüències dels avions $i$ els envia ordres que poden confondre els pilots. La policia sospita que el radiopirata, que actua des de finals de novembre, podria ser un antic pilot o controlador amb la intenció de provocar un accident. Encara que se'l busca per diferents indrets, els investigadors creuen que fa les seves transmissions des de la província de Limburg, a la frontera amb Holanda, i que podria fer-ho des d'un vehicle per evitar ser localitzat. (Avui $23 / 01 / 97)^{16}$

Given the contextual information, the reader of this news article will have a clear enough idea of what radiopirata means. The reader will not think, for example, that a radiopirata is a comical character - a sailor with a wooden leg and an eye patch-who enjoys listening to the radio. Nor will (s)he think that it is someone who makes pirate copies of songs or programs transmitted over the radio. In other words, (s)he will discard more than one possible meaning based on the meanings of the constituents of the neologism (a strategy that clearly could not use a word-formation rule posited to generate neologisms).

The contextual information could lead to an erroneous hypothesis regarding the meaning of the neologism. It could lead one to believe that radiopirata means 'fake air-traffic controller' ("Police are hunting the fake air-traffic controller..."). The presence of the word in other contexts, together with the morphological analysis, is what allows the reader to extract the appropriate definition. In this example, the newspaper article published the day after provided more information: a radiopirata is a radioaficionat 'radio-amateur' who has committed an illegal act.

Detingut el menor que alarmava l'aeroport de Brussel-les. El radioaficionat que, amb missatges falsos als pilots i controladors aeris, feia tres mesos que estava causant alarma a l'aeroport de Zaventem, a Brussel-les, és un menor d'edat, segons van informar ahir fonts oficials. El jove, apassionat de l'aviació i de les seves formes de transmissió, va ser detingut ahir i interrogat. Amb un perfecte domini de l'anglès i de les normes de transmissió, el jove radioaficionat donava ordres falses als pilots. (Avui 24/01/97) ${ }^{17}$

16. 'A radiopirate creates a state of panic in the air traffic surrounding Brussels. He succeeded in sowing panic in both aviators and controllers by transmitting messages relayed to pilots heading in the direction of the Brussels airport. Police are hunting the fake air-traffic controller, who is thoroughly familiar with international aviation terminology in English, able to reach the aircraft frequencies, and capable of sending messages that may confuse pilots. Police suspect that the radiopirate, active since late November, could be a former pilot or controller intending to provoke an accident. Although the search is being conducted in various areas, the investigators believe that the radiopirate transmits his signals from the province of Limburg, on the border with Holland, and that he might be working from a vehicle to avoid being tracked down.' (Avui 23/01/97)

17. 'The junior who threatened the airport in Brussels has been arrested. The radio-amateur who, by transmitting false messages to pilots and air-traffic controllers, had been causing alarm at Zaventem Airport in Brussels for three months, is a junior, official sources said yesterday. The youth, pas- 
From a morphological point of view, neologisms are often characterized by their transparency and by their regularity. Thus, whenever a complex word is involved, in addition to the information contributed by the natural context in which the neologism appears, information provided by the morphological structure of words must be considered too. This structure emerges from the comparison of the neologism with other linguistic expressions that the speaker already knows. In our example, to get an idea of the meaning of radiopirata, the reader could relate this word to:

a) other words that begin with the same morpheme radio-(radionovel-la, etc.), in particular those that refer to people (radioaficionat, radiooient, etc.),

b) the noun pirata and the expressions pirata aeri 'hijacker', pirata informàtic 'hacker', in which pirata means 'person who performs an illegal, delinquent act'; the adjective pirata and the noun radio, and other expressions such as còpia pirata or vídeo pirata, in which pirata means 'illegal, delinquent'.

In sum, in order to encode and decode radiopirata, all other words with the prefixoid radio- are just as important as the members of the word family pirata. This is relevant because, in the expressions pirata aeri 'hijacker', and pirata informàtic 'hacker', the noun pirata no longer means 'a sailor who robs and hijacks ships for plunder' (see Figure 4.a) but 'a person who commits an illegal' (Figure 4.a'), and this is precisely what pirata means in radiopirata. ${ }^{18}$ In fact, the neologism radiopirata could be considered an exocentric compound (in contrast to radioaficionat 'radio-amateur'). It is endocentric, however, if we consider the newly accepted semantic value of the noun pirata as 'a person who commits an illegal act', by which a radiopirata is a 'person who illegally transmits messages by radio'.

The bottom of Figure 4 reveals two patterns. The first pattern, shown in (e), is syntactic, [[NOUN] [ADJ]], and it includes a semantic relation of the type nucleusmodifier (as in pirata aeri). The second pattern, shown in (f), is morphological because it is found in complex words formed with radio-, with an inverse semantic relation between its modifier and nucleus constituents (radiopirata).

sionate about aviation and its transmission systems, was arrested and questioned yesterday. Completely fluent in English and in transmission conventions, the young radio-amateur gave false instructions to pilots.' (Avui 24/01/97)

18. In line with Langacker's work, we have represented the semantic pole for each grammatical unit (in the upper part) and the phonological pole (in the lower part); categorized relations are indicated by solid arrows (an established relation) or dotted arrows (an extended relation). 
(b)

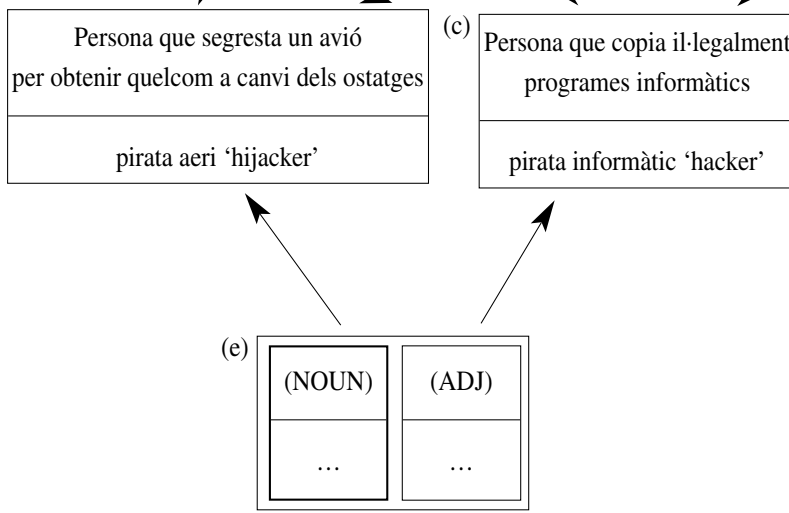

(a')

Mariner que roba i segresta vaixells per obtenir un botí

\begin{tabular}{|c|c|}
\hline pirata \\
\hline
\end{tabular}

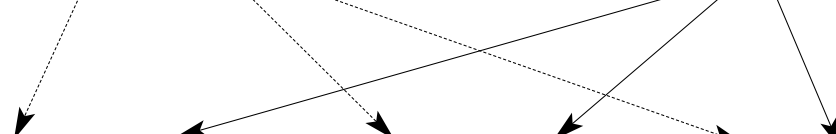

(d) Persona que transmet \begin{tabular}{c} 
il-legalment missatges per ràdio \\
\hline radiopirata
\end{tabular}

(f)

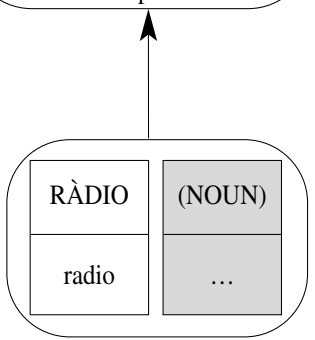

Figure 4. Relation between radiopirata and the noun pirata. ${ }^{19}$

Finally, speakers can also observe the relation between radiopirata 'illegal radio-amateur' and ràdio pirata 'pirate radio station', and other expressions in which the adjective pirata means 'illegal, delinquent': còpia pirata, vídeo pirata. This adjective has suffered a semantic evolution parallel to that of the homonymous noun. Whereas its original meaning was 'related to pirates' (see Figure 5.a), in the sense of 'sailors...' (e.g. vaixell pirata 'pirate ship'), its latest use indicates 'illegal, pirate' (Figure 5.a') (e.g. ràdio pirata 'pirate radio station', vídeo pirata 'pirate video').

19. (a) 'Sailor who robs and hijacks ships for plunder', (a') 'Person who commits an ilegal act', (b) 'Person who hijacks a plane to gain something from hostages', (c) 'Person who illegally copies computer programs', (d) 'Person who illegally transmits messages by radio'. 


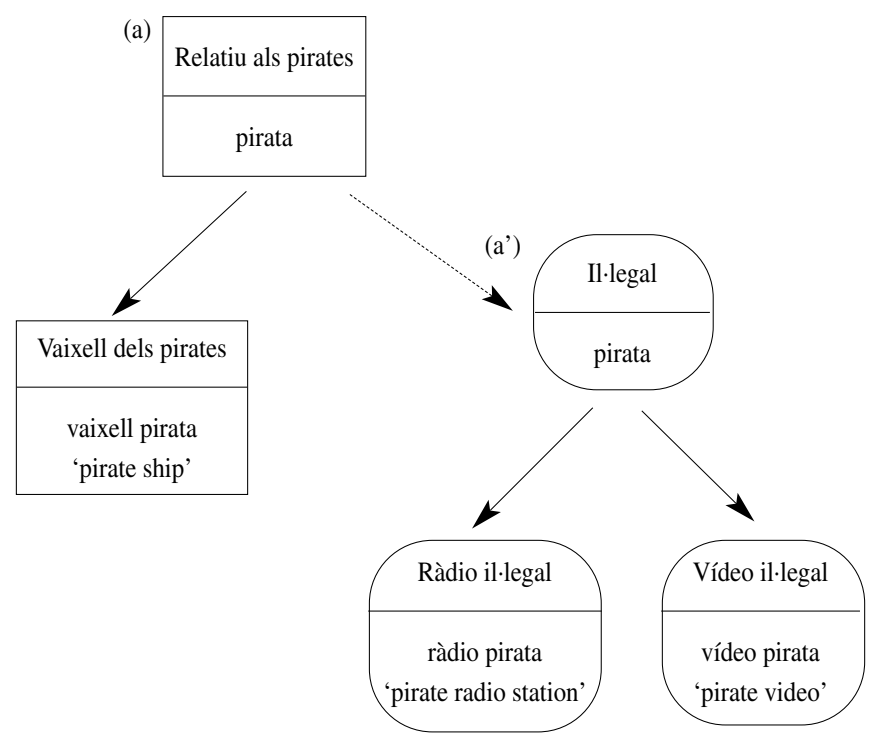

Figure 5. Ràdio pirata and the adjective pirata.

The categorized relations we have represented in figures 4 and 5 following Langacker's morphological connections are equivalent to the Bybee's lexical connections. Speakers may establish the following network of lexical connections for encoding and decoding radiopirata:

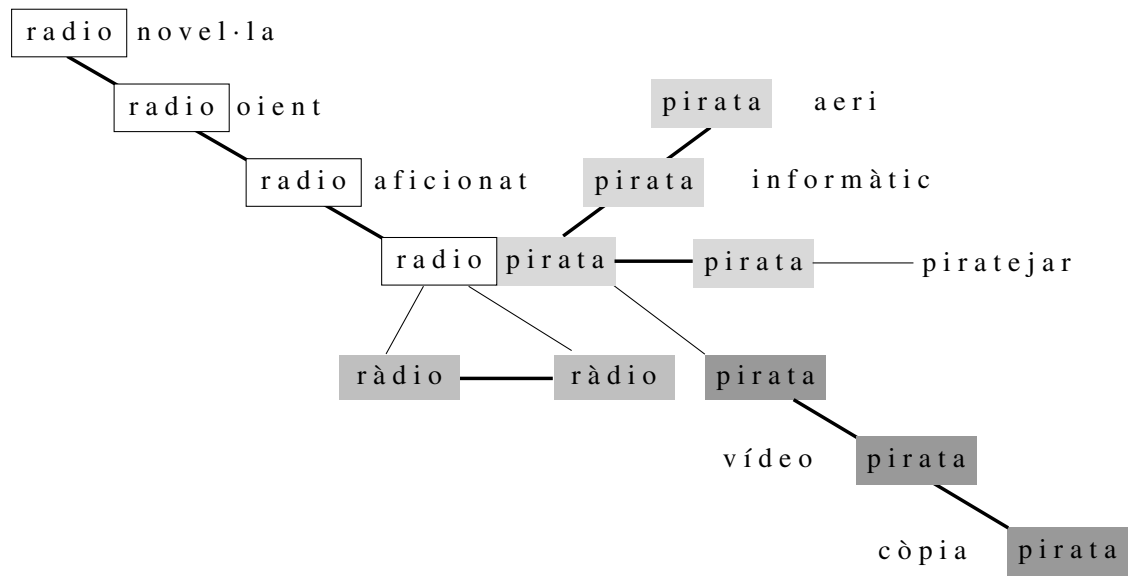

Figure 6. Network of paradigmatic relations in radiopirata. 
This network of paradigmatic relations is composed of connections between words with identical or similar morphemes, and it provides relevant information to the speaker for the purpose of encoding and decoding the neologism radiopira$t a$. Therefore, the formation of this word must be explained not just with regard to the prefixoid radio- but also with regard to all the paradigmatic relations that it maintains with other lexical units sharing common morphemes.

\section{Conclusions}

In this paper we have analyzed a topic in inflection (velar verbs of the second conjugation) and a topic in word formation (the prefixoid radio-) in Catalan within the framework of Bybee's network model. We have shown that the model can explain all possible paradigmatic relations between units of the lexicon, both in morphological relations and in those that go beyond morpheme boundaries or are not associated with any particular morpheme.

We have shown that low-level patterns and the paradigmatic relations of a local nature cannot be considered unnecessary a priori or grammatically insignificant. Following a bottom-up approach within Cognitive Morphology, we have illustrated that low-level patterns offer the advantage of specificity; that is, the great number of common features that they represent can make them more visible and easier to recognize. The role of low-level patterns can be explained by what some experimental studies call perceptive salience, or the ease of perception and recognition of a unit of the linguistic system by speakers (Chapman 1995; Goldschneider and Dekeyser 2001; Langman and Bayley 2002). In conclusion, linguistic analysis and psycholinguistic research point to the importance of incorporating low-level patterns into the morphological model.

\section{References}

Badia, Antoni M. (1994). Gramàtica de la llengua catalana. Barcelona: Enciclopèdia Catalana.

Bauer, Laurie (1997). «Derivational Paradigms». In: Booij, Geert; van Marle, Jaap (eds.). Yearbook of Morphology, 1996. Dordrecht: Kluwer, pp. 243-256.

Bauer, Laurie (2001). Morphological Productivity. Cambridge: Cambridge University Press.

Becker, Thomas (1993). «Back-formation Cross-formation, and "Bracketing Paradoxes" in Paradigmatic Morphology». In: Booij, Geert; van Marle, Jaap (eds.). Yearbook of Morphology, 1993. Dordrecht: Kluwer, pp. 1-25.

Bonet, Eulàlia; Lloret, Maria-Rosa (1998). Fonologia catalana. Barcelona: Ariel.

Booij, Geert (1997). «Autonomous Morphology and Paradigmatic Relations». In: Booij, Geert; van Marle, Jaap (eds.). Yearbook of Morphology, 1996. Dordrecht: Kluwer, pp. 35-53.

Booij, Geert (2005). «Compounding and Derivation: Evidence for Construction Morphology». In: Dressler, Wolfang U.; Kastovsky, Dieter; Pfeiffer, Oskar E; Rainer, Franz (eds.). Morphology and its Demarcations. Selected Papers from the 11th 
Morphology Meeting, Vienna, February 2004. Amsterdam: Johns Benjamins, pp. 109-132.

Bybee, Joan L. (1985). Morphology. A Study of the Relation between Meaning and Form. Amsterdam: John Benjamins.

Bybee, Joan L. (1988). «Morphology as Lexical Organization». In: Hammond, Michael; Noonan, Michael (eds.). Theoretical Morphology. Approaches in Modern Linguistics. San Diego: Academic Press, pp. 119-141.

Bybee, Joan L. (1995). «Regular Morphology and the Lexicon». Language and Cognitive Processes 10.5: 425-455.

Bybee, Joan L. (1996a). «Productivity, Regularity and Fusion: How Language Use Affects the Lexicon». In: Singh, Rajendra (ed.). Trubetzkoy's Orphan. Proceedings of the Montréal Roundtable "Morphonology: Contemporary Responses». Amsterdam: John Benjamins, pp. 247-357.

Bybee, Joan L. (1996b). «Modelo de redes en morfología». Paper presented at the XI Congreso Internacional de la Asociación de Lingüística y Filología de América Latina, Las Palmas, July 1996.

Bybee, Joan L. (1999). «Usage Based Phonology». In: Darnell, Michael; Moravcsik, Edith; Newmeyer, Frederick; Noonan, Michael; Wheatley, Kathleen (eds.). Functionalism and Formalism in Linguistics. I. General Papers. Amsterdam: John Benjamins, pp. 211-242.

Bybee, Joan L. (2001). Phonology and Language Use. Cambridge: Cambridge University Press.

Camus Bergareche, Bruno (1996). «Analogía y morfología contemporánea». Dicenda. Cuadernos de Filología Hispánica 14: 69-78.

Camus Bergareche, Bruno (1997). «Paradigmas y morfología derivativa». Letras de Deusto 27.76: 235-247.

Camus Bergareche, Bruno (1998a). «Paradigmas en morfología derivativa: sustantivos españoles en -ez». Verba 25: 357-374.

Camus Bergareche, Bruno (1998b). «Delimitación de un procedimiento sufijal del español actual: -ata». Anuario de Lingüística Hispánica 14: 73-90.

Camus Bergareche, Bruno; Miranda, Alberto (1996). «En favor de la morfología paradigmática: las formaciones en -ata». Revista Española de Lingüística 26.2: 271-300.

Chapman, Carol (1995). «Perceptual Salience and Analogical Change: Evidence from Vowel Lengthening in Modern Swiss German Dialects». Journal of Linguistics 31.1: 1-13.

Cifuentes, José Luis (1994). Gramática cognitiva: fundamentos críticos. Madrid: EUDEMA.

DeCesaris, J. Anne (1988). Regular Verb Inflection in Catalan. Indiana University, doctoral dissertation.

Derwing, Bruce L. (1990). «Morphology and the Mental Lexicon: Psycholinguistic Evidence». In: Dressler, Wolfgang U.; Luschützky, Hans C.; Pfeiffer, Oskar E.; Rennison, John R. (eds.). Contemporary Morphology. Berlin: Mouton de Gruyter, pp. 249-265.

Geeraerts, Dirk (1992). «Polysemy and Prototypicality». Cognitive Linguistics 3.2: 219-231.

Geeraerts, Dirk (1995). «Representational Formats in Cognitive Linguistics». Folia Linguistica 29.1-2: 21-41. 
Geeraerts, Dirk (2002). «The Interaction of Metaphor and Metonymy in Composite Expressions». In: Dirven, René; Prings, Ralf (eds.). Metaphor and Metonymy in Comparison and Contrast. Berlin: Mouton de Gruyter, pp. 435-465.

Goldschneider, Jennifer M.; DeKeyser, Robert M. (2001). «Explaining the "Natural Order of L2 Morpheme Acquisition" in English: A Meta-Analysis of Multiple Determinants». Language Learning 51.1: 1-50.

Haspelmath, Martin (2002). Understanding Morphology. London: Arnold. Hualde, José Ignacio (1992). Catalan. London \& New York: Routledge.

Langacker, Roland W. (1988). «A Usage-Based Model». In: Rudzka-Ostyn, Brygida (ed.). Topics in Cognitive Linguistics. Amsterdam \& Philadelphia: John Benjamins, pp. 127-161. [Revised version published in Langacker, Roland W. (ed.) (1990). Concept, Image, and Symbol: The Cognitive Basis of Grammar. Berlin: Mouton de Gruyter, pp. 261-288.]

Langman, Juliet; Bayley, Robert (2002). «The Acquisition of Verbal Morphology by Chinese Learners of Hungarian». Language Variation and Change 14: 55-77.

Libben, Gary; de Almeida, Roberto G. (2002). «Is there a Morphological Parser?». In: Bendjaballah, Sabrina; Dressler, Wolfgang U.; Pfeiffer, Oskar E.; Voiekova, Maria D. (eds.). Morphology 2000. Selected Papers from the 9th Morphology Meeting, Vienna, 24-28 February 2000. Amsterdam: John Benjamins, pp. 213-225.

Malkiel, Yakob (1974). «New Problems in Romance Inflexion (I). The Velar Insert in the Present Tense (with an Excursus on -zer/-zir Verbs)». Romance Philology 27: 304-355.

Mascaró, Joan (1983). La fonologia catalana i el cicle fonològic. Bellaterra: Publicacions de la Universitat Autònoma de Barcelona.

Perea, Maria Pilar (2002). «Flexió verbal regular». In: Solà, Joan; Lloret, Maria-Rosa; Mascaró, Joan; Pérez Saldanya, Manuel (eds.). Gramàtica del català contemporani, vol. I. Barcelona: Empúries, pp. 583-646.

Pérez Lagos, Manuel Fernando (1985). «Un nuevo "elemento compositivo" en el DRAE: radio-». Español Actual 44: 87-94.

Pérez Saldanya, Manuel (1998). Del llatí al català. Morfosintaxi verbal històrica. València: Publicacions de la Universitat de València.

Pounder, Amanda (2000). Processes and Paradigms in Word-Formation Morphology. Berlin: Mouton de Gruyter.

Rifón, Antonio (2001). «Paradigmas y series derivativas». Revista de Investigación Lingüística 4.2: 63-81.

Rifón, Antonio (2002). «Organización paradigmática derivativa. Un ejemplo del español». In: Báez, Inmaculada; Pérez, Maria Rosa (eds.). Romeral. Estudios filológicos en homenaje a José Fernández Romero. Vigo: Universidad de Vigo, pp. 213-228.

Roca Pons, Josep (1968). «Morfologia verbal catalana». Estudis Romànics XII: 227-254.

Rubba, Johanna (1993). Discontinous Morphology in Modern Aramaic. University of California, doctoral dissertation.

Rubba, Johanna (1998). «A Network Model of Root-and-Pattern Morphology». Paper presented at the Cognitive Morphology Workshop, Gent, Belgium, 1998.

Vallès, Teresa (2003). «Lexical Creativity and the Organization of the Lexicon». Annual Review of Cognitive Linguistics 1: 137-160.

Vallès, Teresa (2004). La creativitat lèxica en un model basat en l'ús. Barcelona: Publicacions de l'Abadia de Montserrat. 
van Marle, Jaap (1985). On the Paradigmatic Dimension of Morphological Creativity. Dordrecht: Foris.

van Marle, Jaap (1994). «Paradigms». In: Asher, Ronald E.; Simpson, John M. Y. (eds.). The Encyclopedia of Language and Linguistics, vol. VI. Oxford: Pergamon, pp. 2927-2930.

Viaplana, Joaquim (1984). «La flexió verbal regular del valencià». In: Casanova, Emili (ed.). Miscel-lània Sanchis Guarner. Estudis en memòria del professor Manuel Sanchis Guarner: Estudis de llengua i literatura catalanes, vol. I. València: Universitat de València, pp. 391-407. [Revised version published in: Ferrando, Antoni (ed.) (1992). Miscel-lània Sanchis Guarner, vol III. València: Departament de Filologia Catalana de la Universitat de València; Barcelona: Publicacions de l'Abadia de Montserrat, pp. 381-423.]

Viaplana, Joaquim (2005). «Velar verbs and Verbal Classes in Catalan». Catalan Journal of Linguistics 4: 225-247.

Wheeler, Max W. (1993). «Changing Inflection: Verbs in North West Catalan». Mackenzie, David; Michael, Ian (eds.). Hispanic Linguistic Studies in Honour of F. W. Hodcroft, Llangrannog: Dolphin, pp. 171-206. 